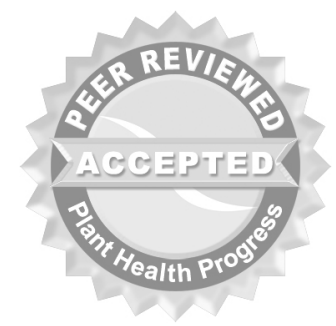

(c) 2007 Plant Management Network.

Accepted for publication 29 December 2007. Published 19 February 2007.

\title{
First North American Record of Powdery Mildew of Cleome hassleriana Caused by Leveillula taurica
}

\author{
R. Sampangi, Extension Support Scientist, Parma Research and \\ Extension Center, University of Idaho, Parma 83660; D. A. Glawe, \\ Plant Pathologist, Department of Plant Pathology, Washington State \\ University, and Professor, College of Forest Resources, Box 352100, \\ University of Washington, Seattle 98195; and S. K. Mohan, \\ Extension Plant Pathologist, Parma Research and Extension Center, \\ University of Idaho, Parma 83660
}

Corresponding author: Dean A. Glawe. glawe@wsu.edu

Sampangi, R., Glawe, D. A., and Mohan, S. K. 2007. First North American record of powdery mildew of Cleome hassleriana caused by Leveillula taurica. Online. Plant Health Progress doi: 10.1094/PHP-2007-0219-02-BR.

The introduced plant pathogen Leveillula taurica (Lév.) G. Arnaud (anamorph = Oidiopsis sicula Scalia) occurs on a range of hosts in the Pacific Northwest (PNW), including onion (Allium cepa L.) (4). In an onion cultivar trial conducted in Malheur Co., Oregon, powdery mildew caused by L. taurica was observed in the first week of September 2006 on 5 out of 46 cultivars. Examination of crops, weeds, and other plants in the vicinity of the field for possible sources of inoculum led to the discovery of a single plant of Cleome hassleriana Chod. (common name: pink queen, family: Capparaceae), growing in a nearby garden, infected with L. taurica. This report documents the first record of L. taurica on a species of Cleome (spiderflower) in North America.

Characteristics of powdery mildew on $\mathrm{C}$. hassleriana were as follows. Symptoms were observed on the plant that was beginning to senesce after flowering. Leaves and petioles exhibited effuse to dense, white floccose colonies (Fig. 1). Symptoms were most severe on older infected leaves which became necrotic and desiccated. Infected leaflets curled inwards from margins. The fungus formed dense mycelial mats on abaxial surfaces, later spreading to adaxial surfaces and petioles. All leaves (about 10) except the youngest 3 or 4 were infected. Infected leaves usually became completely covered with mycelia. Conidiophores emerged from stomata singly or in groups (Fig. 2). Conidia were hyaline, of two kinds (Fig. 3): primary (first-formed) conidia were lanceolate with narrowed apex and relatively broad base, (46-)48-67(-77.5) $\times(14-) 14.5-19.5$ (-20.5) $\mathrm{mm}$; later-formed (secondary) conidia were elongate to cylindrical, (43.5)44-66.5(-70.5) × 14-19.5(-20) $\mu \mathrm{m}$. Chasmothecia (Fig. 4A) were observed on leaves and petioles, became dark brown to black at maturity, 220-280 $\mu \mathrm{m}$ in diameter, and the dorsal surface frequently was concave. Asci were clavateovoid, short-stipitate, about $80 \times 35 \mu \mathrm{m}$, containing two ascospores. Ascospores (Fig. 4B) were subhyaline to pale yellow, multi-guttulate, ellipsoid-ovoid, (20.5-) 29-35(-36.5) × 15.5-23(-24) $\mathrm{\mu m}$. 


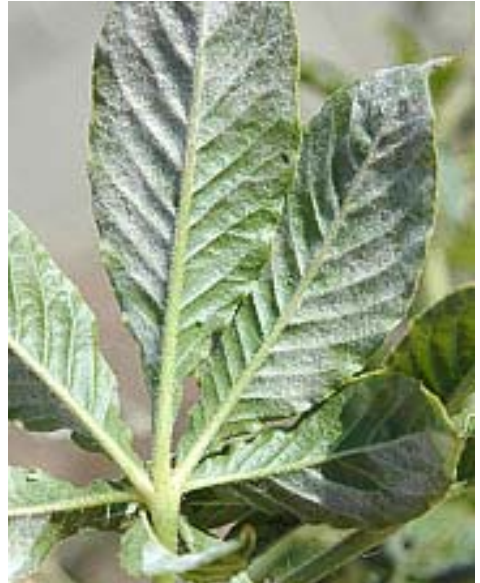

Fig. 1. Powdery mildew of Cleome hassleriana caused by Leveillula taurica.

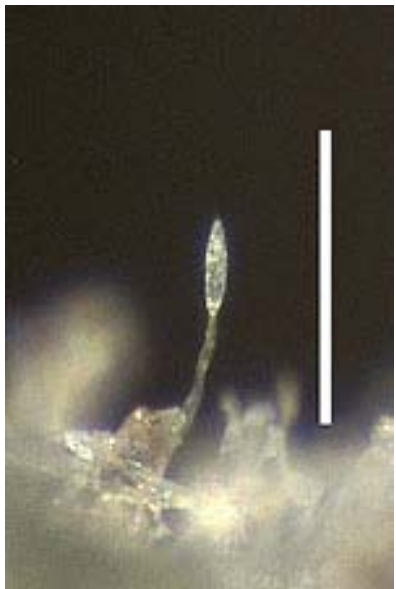

Fig. 2. Conidiophore of Leveillula taurica producing a single primary conidium on Cleome hassleriana. Scale bar $=250 \mu \mathrm{m}$.

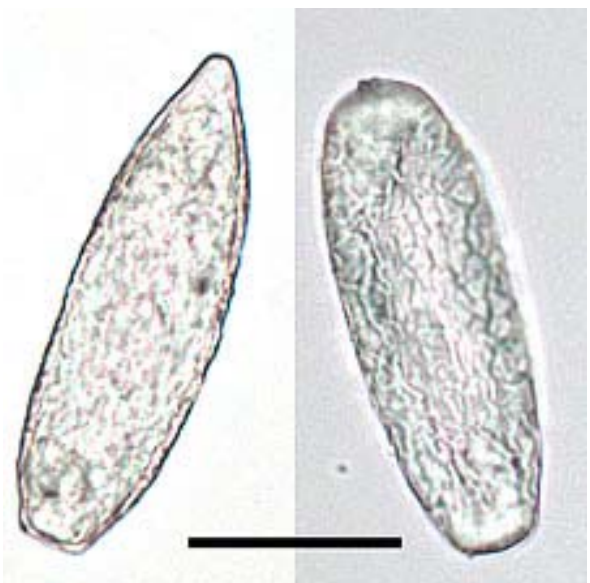

Fig. 3. Primary (left) and secondary (right) conidia produced by Leveillula taurica on Cleome hassleriana. Scale bar $=25 \mu \mathrm{m}$.

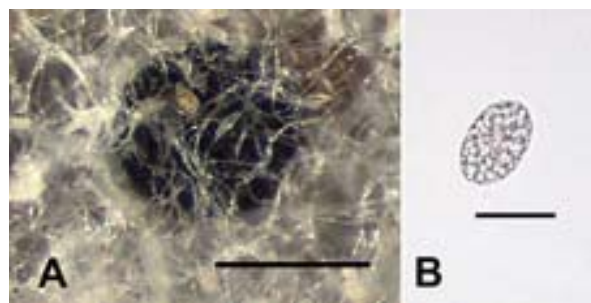

Fig. 4. Leveillula taurica on Cleome hassleriana. (A) Chasmothecium and associated mycelium. Scale bar $=250 \mu \mathrm{m}$. (B) Ascospore. Scale bar $=25 \mu \mathrm{m}$.

The fungus was determined to be L. taurica on the basis of anamorph and teleomorph morphology (1). A fungus identified as Erysiphe polygoni DC was reported previously from an unidentified species of Cleome in California (2). Leveillula taurica is easily distinguished from Erysiphe species on the basis of dimorphic conidia (1), making it unlikely that the California report was based on L. taurica. Although the anamorph of L. taurica was reported earlier on glossy leaf genotypes of onion (5) from Canyon Co., ID, this is the first report of its teleomorph in the Treasure Valley (eastern Oregon and southwest Idaho). Leveillula taurica has an extremely broad host range (1) and was previously reported from C. hassleriana in Egypt, Italy, Romania, and South Africa (2).

Cleome hassleriana is planted commonly as a flowering annual in gardens, and it reseeds easily. All previous records of L. taurica from PNW, except the one from greenhouse-grown Triglochin maritima (3), are of only the conidial state. This discovery of the teleomorph suggests that it may contribute to genetic variability of $\mathrm{L}$. taurica in the region and that $\mathrm{C}$. hassleriana could play a role in overwintering of this pathogen in the Treasure Valley. This agricultural region produces a diverse range of crops that could be impacted by this pathogen. 
Literature Cited

1. Braun, U. 1987. A monograph of the Erysiphales (powdery mildews). Beih. Nova Hedwigia 89:1-700.

2. Farr, D. F., Rossman, A. Y., Palm, M. E., and McCray, E. B. 2004. Online. Fungal Databases, Systematic Botany \& Mycology Laboratory, ARS, USDA.

3. Glawe, D. A., Dugan, F. M., Liu, Y., and Rogers, J. D. 2005. First record and characterization of a powdery mildew (Erysiphales) on a member of the J uncaginaceae: Leveillula taurica on Triglochin maritima. Mycolog. Prog. 4:291298.

4. Glawe, D. A., Grove, G. G., and Nelson, M. 2006. First report of powdery mildew of Gaillardia $\times$ grandiflora (blanket flower) caused by Leveillula taurica in North America. Online. Plant Health Progress doi:10.1094/ PHP-2006-0112-01-BR.

5. Mohan, S. K., and Molenaar, N. D. 2005. Powdery mildew caused by Leveillula taurica on glossy leaf genotypes of onion in Idaho. Plant Dis. 89:431. 